\title{
ДУХОВНІ АСПЕКТИ СТАНОВЛЕННЯ ФУНДАМЕНТАЛЬНИХ ЦІННОСТЕЙ ОСОБИСТОСТІ В ГРОМАДЯНСЬКОМУ СУСПІЛЬСТВІ
}

\author{
Н.В. Скотна
}

\section{1 Громадянське суспільство і процес соціалізації осо- бистості}

Для аналізу специфічних цінностей громадянського суспільства слід звернутися до розгляду основних його характеристик, які поступово проявлялись в ході розвитку сучасного суспільства та його теоретичного пізнання. Концепція громадянського суспільства, що почала формуватися на зорі Нового часу, розвивалась і змінювала свій зміст паралельно з розвитком суспільної реальності, які вона позначала. Потім, з другої половини XIX ст. і до другої половини XX ст. про неї майже забули - як політики, так і більшість науковців. А коли у 80-х роках XX ст. це поняття знову перетворилося на ключове слово інтелектуальних дискусій, виявилось, що не всі вкладають у нього однаковий зміст.

За кілька сот років своєї історії термін «громадянське суспільство» став полісемантичним: у різних країнах і в різні епохи йому було надано різних значень. Тому перед дослідниками постали завдання: 1) точніше окреслити нормативний зміст поняття «громадянське суспільство», визначити, що воно являє собою як ідеальний тип; 2) визначити його «межі», відокремивши від інших суспільних феноменів - заради операціоналізації поняття та емпіричного дослідження явища; 3) вивчити моделі громадянського суспільства через з'ясування його спільних і відмінних рис в різних країнах. Виконанню цих завдань сприяє періодизація розвитку ідеї і практики громадянського суспільства, прийнятним варіантом якої можна вважати три стадії, виділені професором Каліфорнійського

Актуальні проблеми духовності

(Відп. ред.: Я.В. Шрамко)

Кривий Ріг (2005), 356-365 
університету Джеффрі Александером й умовно названих ним «громадянським суспільством -I, -II, -III» [10, с. 412-418].

Застосувавши термін societas civitas (пізніше: civil society - цивільне суспільство) для означення нових суспільних порядків, що утверджувались, на їхніх очах, мислителі Нового часу започаткували властиве й нинішнім концепціям громадянського суспільства протиставлення суспільства і держави, їх трактування як певного типу антиномію, за допомогою якої суспільна система описується як поділена на дві взаємопов'язані та взаємообумовлені, проте відмінні і, в ідеалі, автономні сфери: політичну і громадську (соціальну, соціетальну). Життя в останній грунтується на ідеях індивідуальної свободи громадян та автономності громад, їх праві творити спілки та асоціації, захищати свої інтереси, запобігати або протистояти можливій сваволі державних посадовців.

Ранні концепції громадянського суспільства наголошували на економіці як його головній складовій частині. Адже саме тут індивіди проявляли себе незалежними суб'єктами суспільної діяльності i, покладаючись на механізми ринкової саморегуляції, прагнули якомога меншого втручання держави у свої справи. Laissez faire, laissez passer! ${ }^{1}$ - таким було головне гасло раннього капіталізму, яке й досі використовується як заклик до невтручання держави в сферу бізнесу. Проте, це не означало, що держава не відігравала жодної ролі в становленні громадянського суспільства. Її функції полягали в творенні та впровадженні в життя законів, що були втіленням загальної волі громадян, оберігали непорушність їхніх прав та свобод. В цьому полягає одна з найважливіших цінностей громадянського суспільства - автономія і саморегуляція громадянами їх життя.

У XVIII ст. поряд з економікою з'явилась інша автономна сфера суспільного життя: сфера громадянського неполітичного спілкування з власною громадською думкою. Усі справи, що вважались об'єктом громадської зацікавленості, було визнано і сферою громадянської активності, в яку також не мала втручатися держава. Приватне життя остаточно відокремилось від громадського (публічного), а публічна сфера поділилася на дві: політичну і громадянську (сферу відкритості). 3 того часу існує переконання, що само регульована економіка і громадська думка $є$ тими двома шляхами, якими суспільство може дійти до деякої єдності поза межами політичних структур. Саме вони зробили громадянське суспільство - суспільством і допомогли подолати деструктивні тенденції та ризик його можливого розвалу. Другою цінністю громадянського суспіль-

\footnotetext{
${ }^{1}$ «aissez faire, laissez passer» (фр.) - «Дозволяйте робити (що забажають), дозволяйте йти (куди забажають)» (тобто, «Надайте свободу дій, не заважайте») - фраза належить французькому економісту Ж.К.Гурне, який у 1758 р. вимовив її на асамблеї фізіократів для позначення політики вільного, нічим не обмеженного розвитку ринкового господарства.
} 
ства, можна, таким чином, зазначити недоторканість приватності і право на активне виявлення і захист приватних інтересів у публічній сфері.

Окрім ствердження первинності й автономності громадянського суспільства стосовно держави, значна увага в цей період була приділена обгрунтуванню його моралі, етики та цивілізаційної ролі (слова цивільний і цивілізований-одного кореня). Адам Фергюссон, зокрема, чітко протиставив громадянське (цивільне) суспільство суспільствам диким і варварським, а головну ознаку цивілізованості вбачав у повільному, але невпинному усуненні насильства із взаємин між людьми [5, с. 116]. Саме звідси бере початок тенденція етизації поняття «громадянське суспільство», особливо в англійській соціальній філософії, підкреслювання ролі в ньому моральності, вихованості, повсякденної та політичної культури. Третьою цінністю громадянського суспільства виступає, таким чином, толерантність до іншої позиції та утвердження вищості соціальної різнорідності (плюралізму).

Нероздільність моралі і права як ще одну цінність громадянського суспільства, яка повинна втілюватись у принципах правової держави, що створює сприятливі умови для функціонування громадянського суспільства, обгрунтовували німецькі філософи Іммануїл Кант та Г.В.Ф. Гегель. Боготворячи державу як втілення всезагальності, як «дійсність Розуму» i «ходу Бога в світі», Гегель усе ж таки вважав ідеалом не будь-яку державу, а лише конституційну монархію. Він виступав за кодифікацію законів, публічність, судочинства, створення суду присяжних, формулюючи тим самим важливі принципи правової держави, реалізація яких робила можливим функціонування громадянського суспільства. Його Гегель пов'язував з системою егоїстичних потреб індивідів та з публічною сферою суспільного життя, яка певним чином узгоджувала і регулювала їх задоволення.

Елементами громадянського суспільства, за Гегелем, є: система потреб; система правових установ, що здійснює судочинство; поліція та корпорації $[1, \S 188]$. Кожний індивід прагне вдовольнити лише свої специфічні егоїстичні потреби й цілі, але зробити це повною мірою він може тільки у взаємодії з іншими людьми. Особливого значення Гегель надавав корпораціям (або громадянським спілкам), що об'єднують індивідів за родом діяльності і за здатністю до праці. Завдяки їх діяльності і суперечності між індивідами згладжуються, а зв'язки між ними синтезуються в державі - «самоусвідомлюючій субстанції, розвиненій до органічної діяльності» [4, с.261]. Для позначення громадянського суспільства він вживає термін bürgerliche Gesellschaft - «бюргерське» (горожанське, міщанське) суспільство, зміст якого пізніше був зведений марксистами до буржуазного суспільства у класовому розумінні [9, с. 54].

Дослідники громадянського суспільства в наш час найбільше цінують 
у спадщині німецького філософа те, що він звернув увагу на складність та неоднозначність громадянського суспільства, вказав на притаманні йому суперечності i, в певному сенсі, був провісником концепції плюралізму. 3 іншого боку, його ідеї стають нині у пригоді тим, хто намагається окреслити нову модель громадянського суспільства, яка відповідала б умовам і потребам держави загального добробуту. Інститути такого суспільства, турбуючись покращанням добробуту громадян, мусили б бути задіяні у певних формах зв'язків з урядом, поєднуючи індивідуалістичні вартості 3 підходами, що притаманні м'яким формам корпоративізму.

Та чи не найбільш актуальним для нашого часу з усіх творів цього періоду є книга французького дослідника Алексіса де Токвіля «Демократія в Америці», що була написана у 1832 р. В ній уперше було показано тісний зв'язок і в певному розумінні-тотожність громадянського суспільства та демократії. Токвіль започаткував соціокультурний підхід до розуміння громадянського суспільства, що акцентує увагу на моральному та соціопсихологічному впливові мережі громадських асоціацій, зайнятих вирішенням повсякденних «малих» справ. Саме ці організації формуюють «місцеві й особисті свободи», створюють необхідне для демократії активне соціальне поле, поширюють дух солідаризму, терпимості та кооперації, а також створюють ситуацію наявності «пильного громадського ока», що повсякчас слідкує за владою [10, с. 412-418]. Така інтерпретації видається найбільш плідною при розгляді громадянського суспільства як «стратегії переходу» до демократії в посткомуністичних суспільствах, бо вона акцентує увагу не стільки на негативних функціях громадянського суспільства (бути противагою владі, служити заборолом проти диктатури), скільки на позитивних (створювати громадянську культуру, формувати сприятливе для демократії соціальне середовище).

\section{2 Соціально-психологічні чинники становлення фундаментальних цінностей особистості}

Громадянське суспільство - це соціальне утворення, яке не завжди існувало в історії людства, попри те, що деякі дослідники схильні вбачати його прототип ще у античному полісі [8, с.7-17]. Утвердження громадянського суспільства як стійкого соціального феномену спочатку у європейській, а потім і у світовій історії пов'язане з формуванням таких соціальних структур (подолання відносин особистої належності (рабовласництво) та залежності (феодалізм) та визнання юридичної рівності всіх громадян), а також такої психологічної атмосфери, за якої індивіди відчувають відкриті обрії для власної самореалізації. Духовного наповнення психологічна атмосфера громадянського суспільства набуває у національ- 
ній ідеї, яка виражає цілісність виховного впливу громадянського суспільства (аж до такого поняття, як менталітет та національний характер).

Таким чином, досліджуючи психологічну атмосферу громадянського суспільства, слід передусім звертатись до аналізу глибинних її структур, які спрямовують нас до аналізу національного характеру, цивілізаційних рис певної культури. На поверхню свідомості наріжні риси національного характеру виходять, зокрема, у натовпі [7], однак свою визначальну дію на громадянське суспільство країни вони зберігають постійно. Дещо інший вимір психологічної атмосфери громадянського суспільства дозволяє осягнути цивілізаційний його аналіз.

Різні моделі громадянського суспільства також можна зробити інструментом аналізу національних відмінностей у функціонуванні громадянського суспільства. Адже не важко помітити, що з часу виникнення громадянського суспільства і дотепер його найтиповіші риси та вплив на політику були різними навіть на Заході. Демократія перемогла там попри ці відмінності (а може навіть і завдяки їм). I молоді демократичні держави повинні брати це до уваги, розробляючи стратегію відродження чи побудови громадянських суспільств у своїх країнах.

Згадаймо, що французький граф Алексіс де Токвіль був приємно вражений, побачивши, як охоче вступають пересічні американці в асоціації заради вирішення своїх спільних проблем. «Всюди, - каже Токвіль, - де на чолі певної справи ви побачите уряд у Франції, або титуловану особу в Англії, у Сполучених Штатах ви 3 певністю знайдете асоціацію». Культура політичного узгодження і компромісу, розділена усіма, була наслідком американського способу життя і на той час не була властива Європі, зокрема завжди готовому до революційних вибухів французькому суспільству.

Хоч соціальні та політичні інститути Французької республіки формувалися у той самий час, що і США, хоч вони грунтувалися фактично на тих самих ідеологічних засадах (визнання природних прав, ідей народного суверенітету та суспільного договору), форми суспільної взаємодії, солідарності і політичної активності були тут зовсім інакшими - більш політизованими, радикальними, організованими навколо ліній класового поділу тощо. Вже тоді люди тут більшою мірою залежали від держави та державної політики. У деяких аспектах французькі соціальні інститути могли бути більш демократичними, у деяких - більш аристократичними, але завжди вони були менш ліберальними.

Сказане не означає, що в країнах, де форми громадянської взаємодії відрізнялися від англо-саксонських, громадянське суспільство було нерозвиненим. Воно було інакшим: мало більшу частку комунітаризму чи революційності, було більш переплетеним з політикою. Більш ідеологізованим тощо. I концепції, що формулювалися в таких суспільствах, також 
неминуче відрізнялися від тих, що формулювалися на англосаксонському досвіді. Можна сказати, що за класифікацією Н. Розенблюм, у Західній Європі більш поширеною завжди була модель демократичного громадянського суспільства (яка, передовсім, є засобом політичної соціалізації), у той час як у США домінували описані Токвілем інститути поза політичного посередницького громадянського суспільства.

Щоправда, рухаючись далі на Схід, побачимо, що в Німеччині, де держава розглядалася як «посередник бюргерського суспільства, його опікун, вихователь і каратель», громадянське суспільство не було таким незалежним, як у вище означених країнах. Це так званий напівзахідний варіант розвитку стосунків держави і громадянського суспільства. Нарешті, у країнах Східної Європи (за винятком Росії) виникає «освічене громадянське суспільство», «суспільство-культура», що згодом розвивається у повноцінну націю. Так само, як і на Заході, громадянське суспільство тут зароджується незалежно від держави, однак на відміну від Заходу воно спочатку поширюється тільки на сферу освіти і культури [11, с. 82].

Отже, переходячи від країни до країни, ми можемо зустрітися з piзними по формі виявами тієї самої сутності, визначеної в іiї загальних, спільних рисах. На рівні емпіричних моделей громадянського суспільства ми бачимо істотні відмінності навіть у межах того громадянського суспільства, яке, на перший погляд, видається просто західним і просто ліберальним.

Чим розвинутішим є громадянське суспільство, тим легше громадянам захищати свої інтереси, тим більшими є їхні можливості щодо самореалізації в різних сферах суспільного життя і тим меншою $є$ небезпека узурпації політичної влади тими чи іншими її органами або окремими особами. Відстоюючи матеріальну і духовну незалежність людини від держави, домагаючись правової гарантії такої незалежності захисту приватних і суспільних інтересів людей, громадянське суспільство активно сприяє процесам політичної демократизації, набуття державою ознак держави правової. Рівновага між громадянським суспільством і державою $\epsilon$ важливим фактором стабільного демократичного розвитку, а порушення іï веде до гіпертрофії владних структур, відчуженості і політичного безсилля народу.

Але, з іншого боку, громадянське суспільство залежить від держави i не може набути розвинених форм в умовах політичного насильства й тиранії. Тому зворотній зв'язок у стосунках громадянського суспільства і правової держави - дуже важливий. Визнаючи автономність громадянського суспільства, правова держава має реагувати на запити і потреби асоційованого громадянства, видавати відповідні законодавчі акти та слідкувати за їх виконанням, іншими словами, вона повинна створити ситуацію правової захищеності громадян, сформувати сприятливе право- 
ве поле для діяльності створюваних ними громадських інститутів. Захищеність конституційних прав $€$ фундаментальною умовою автономності громадянського суспільства і забороною проти беззаконного правління.

Відомий український правник і політолог Богдан Кістяківський підкреслював взаємозалежність, взаємну обумовленість правової держави і громадянського суспільства. «Правильне і нормальне справляння державних функцій у правовій державі залежить од самодіяльності суспільності і народних мас, - писав учений. - Без активного ставлення до правового порядку і державних інтересів, що виходить із надр самого народу, правова держава немислима». Але так само й громадянське суспільство неможливе без правової держави, яка «неодмінно передбачає широкі громадянські та народні організації, завдяки яким зростає і їі власна зорганізованість» [6, с. 252-253].

\section{3 Реалії українського громадянського суспільства та виховання особистості}

Перш ніж перейти до аналізу сьогодення українського громадянського суспільства, варто згадати основні віхи його історії. Вони підтверджують нашу думку про первинність громадянського суспільства щодо держави, як і інших соціальних інститутів. Тривалий період слабкої державності у XVI-XVIII століттях в Україні не завадив розвою доволі розвиненого громадянського суспільства. Досить лише згадати братські школи, розвиток правової думки (конституція Пилипа Орлика, залучення у литовській версії до акту Habeas Korpus), місцеве самоврядування.

Пізніше саме ці традиції були осмислені у теорії громад М.Драгоманова, концепції самоврядності М.Костомарова та вже згадуваній доволі потужній традиції вітчизняної політичної, правової та соціологічної науки. Доволі докладно еволюцію вітчизняних ідей щодо самоврядування і громадянського суспільства подають Пасько [8].

Період громадянської війни 18-20 років ХХ століття, а також бурхливе державотворення у різних його формах було свідченням напруженого життя громадянського суспільства, яке на тривалий час було заховане під кригу ідеологічного пресу марксизму у його тоталітарній радянській версії. Хоча певною мірою громадянське суспільство України підлаштувалось до соціальних інститутів радянського режиму, однак ці інститути переважно мало задовольняли його потреби. Тому в Україні в одній з перших радянських республік ще за Радянського Союзу наприкінці 80-х років розгорнувсься широкий громадський національно орієнтований рух, який і отримав назву Народного Руху України. Цей громадянський рух сприяв становленню сучасної української державності. Знаковим $є$ і той 
факт, що вирішальні і рішучі політичні дії були у критичний момент виконано саме громадським студентським рухом (історична наметова революція на нинішньому майдані Незалежності та помаранчева революція).

Оскільки у перехідних до демократії суспільствах 80-х - початку 90-х років існувала передреволюційна або революційна соціальна реальність, а не така, яку описав Токвіль, у своїй «Демократії в Америці», то не дивно, що перевагу тут також отримало «демократичне громадянське суспільство». Зосередження уваги на наслідках протистояння груп та об'єднань, що належать до громадянського суспільства, репресивній державі було закономірним явищем для періоду, коли сила тоталітаризму була підірвана саме завдяки масовим акціям громадянського суспільства. Однак у теоретичному плані такий підхід веде до того, що до уваги береться лише одна, причому не найрозвиненіша його модель. У деяких випадках політизація доходить до ототожнення «громадянського суспільства» із свідомо створеною опозицією до владних структур. I тоді громадянське суспільство фактично не відокремлюється від політичного суспільства, на що справедливо звернули увагу Е. Арато та Дж. Коен [2], [3].

Політизованість громадянського життя і концепції громадянського суспільства - це лише одна з найбільш істотних особливостей моделі громадянського суспільства, що може скластися в молодих демократичних державах. Інша пов'язана з тим, що можна назвати навздогінною моделлю розвитку цих країн, за якої визначальну роль в усіх сферах суспільного прогресу відіграє духовно-інтелектуальна еліта - інтелігенція, що прагне «підтягнути» свій народ до здобутків світової цивілізації. Ця риса змінює модель громадянського суспільства, яке тут формується, з масового, закоріненого в народі на «інтелігентське» або як каже, «освічене» (Р. Шпорлюк), тобто таке, що твориться людьми, які розуміють суть і цінність вибору, зробленого нацією на доволі пізньому етапі її розвитку, необхідність інституалізації громадянського суспільства як «трансцедентно-логічної передумови демократії» (Дж. Кін).

3 цієї причини в усіх країнах навздогінного розвитку, у тому числі й в Україні, саме інтелектуали нерідко перебувають в опозиції до влади, гуртують народ, виконують роль «ферменту», без якого не може виникнути громадянське суспільство. Йдеться про початкові етапи розвитку, про період відродження громадянського суспільства та про те, звідки має взятися ініціатива, що грунтується на розумінні суті і значення громадських форм діяльності. Розвинене громадянське суспільство у будь-якому варіанті охоплює широкі верстви громадянства і розв'язує значне коло проблем, що стосуються загалу.

У свою чергу, громадянське суспільство вкрай необхідне для утвердження демократичного врядування, бо як пише Джон Кін, там, «де немає громадянського суспільства, не може бути взаємодії й обміну дум- 
ками між громадянами, здатними публічно обирати свої ідентичності, шанувати свої обов'язки в рамках політично-правової структури, яка забезпечує мир між громадянами, добре функціонування уряду, соціальну справедливість та - перш за все-діє відповідно до принципу, що влада має бути підзвітна суспільству» [5, с.78]. 3 цієї точки зору, яка цілком відповідає також і нашим обгрунтуванням, важко переоцінити виховну функцію громадянського суспільства щодо особистості.

За будь-яких обставин, утвердження громадянського суспільства в молодих демократіях - непроста і тривала справа. «Народження та відродження громадянського суспільства завжди пов'язане з небезпеками», зазначає Дж. Кін, адже «воно дарує свободу деспотам та демократам рівною мірою». 3 цієї причини «незріле громадянське суспільство може перетворитися на поле битви, на якому, завдяки громадянським правам і свободам, лисиці насолоджуються свободою полювати на курей» [5, с. 51].

Отже теорія громадянського суспільства грунтується на ідеї автономності та індивідуальної свободи громадян, невтручання (щонайменше) держави в життя громадянського суспільства. Відносини і взаємовплив громадянського суспільства і держави-цих двох підсистем єдиної суспільної системи - $\epsilon$ визначальними у забезпеченні демократичного розвитку країни. Однак, ці відносини залишаться формальними і безживними, якщо вони не будуть наповнені прагненнями і зусиллями громадян країни. Тому в кінцевому результаті доля демократії в Україні залежить від послідовності і відповідальності українських громадян у своїх діях. До цієї відповідальності схиляє українців багатовікова традиція громадянського самоврядування, національна гордість, нарешті природний розум і життєва мудрість. Все це у своїй єдності формується змалечку, супроводжує до смерті і передається нащадкам - адже виховання в собі свободи і любові до батьківщини є справою всього життя не лише громадянина, але й усього громадянського суспільства, усього народу.

Таким чином, виховна функція громадянського суспільства полягає передусім у формуванні не лише поваги до провідних суспільних цінностей та соціальних інститутів, але й у формуванні вміння відрізняти ці соціальні інститути від цінностей, які вони захищають. Це означає, що справжній громадянин не лише віддасть своє життя за певний соціальний інститут, якщо це буде потрібно, але й віддасть усе життя щоб змінити цей соціальний інститут, якщо, на його глибоке переконання, це буде відповідати потребам його громадянського сумління. Врешті-решт, сумління - та точка опертя, спираючись на яку громадянин може зрушити навіть державу, якщо порівняти його з Арістотелем, який готовий був зрушити з місця Землю, якщо йому дадуть точку опертя. Саме сумління $є$ тим, що підказує нам, що таке «добре» і що таке «погано». Саме сумління $є$ непідвладним соціальним інститутам, але до певної міри під- 
судним схваленню чи осуду співгромадян. Відштовхуючись від власного сумління, приймають громадяни ті рішення, які визначають сенс їх життя. Саме сумління поступово утворюється і розвивається за допомогою різних форм громадянського суспільства.

\section{4 Бібліог рафія}

[1] Гегель Г.В.Ф. Философия права. - М.: Мысль. - 1990.

[2] Apamo E., Коен Дж. Відродження, занепад і реконструкція концепції громадянського суспільства // Політична думка. -1996 . - №1.

[3] Коэн Дж., Арато Э. Гражданское общество и политическая теория. - М.: Весь мир, 2003.

[4] История политических учений. Часть I / Под ред. проф. К.А. Мокичева. - М.: Высшая школа, 1973.

[5] Кін Дж. Громадянське суспільство. Старі образи, нове бачення.Київ: КІС; АНОД, 2000.

[6] Кістлківський Б. Держава і особистість / Вибране.-К.: Абрис, 1996.

[7] Лебон Г. Психология толп // Психология толп. - М.: Институт психологии РАН, Изд-во КСП +, 1998.

[8] Пасъко I., Пасько Я. Громадянське суспільство і національна ідея.-Донецьк: Східний видавничий дім, 1999.

[9] Рябчик M. Гримаси етатизму, або чому в нас нічого не виходить? // Сучасність. - 2000. - №12.

[10] Шпорлюк Р. Досліджуючи драму історії, або національні шляхи до сучасності // Зустрічі. - 1991. - №2.

[11] Токвіль А.Д. Про демократію в Америці.-К.: Всесвіт, 1999. 